\title{
The Work and Role of Extracurricular Clubs in Fostering Student Creativity
}

\author{
Kristina Kuhar $^{1}$, Jakov Sabljić ${ }^{1}$ \\ ${ }^{1}$ Josip Juraj Strossmayer University of Osijek, Faculty of Humanities and Social Sciences, Croatia \\ Correspondence: Kristina Kuhar, Josip Juraj Strossmayer University of Osijek, Faculty of Humanities and Social \\ Sciences, Croatia
}

Received: December 24, 2015

Accepted: December 30, 2015 Online Published: January 20, 2016

doi:10.11114/jets.v4i4.1319

URL: http://dx.doi.org/10.11114/jets.v4i4.1319

\begin{abstract}
Extracurricular activities play an important role in the educational process as they provide students with the opportunity to deepen their knowledge and develop various skills, meet their creative needs and acquire the culture of free time. They also provide space for a closer relationship between the club coordinators and students, for students' spontaneous behaviour, and freedom in organizing and performing activities. Such activities abandon the traditional teacher-centred teaching what makes them conducive for fostering student creativity.

The purpose of this research was to determine the role of literary, poetry recitation, drama, journalist (radio) and film clubs in fostering the student creativity. First, by reviewing the 2014/2015 curricula of primary and secondary schools in Osijek (Croatia), the paper identifies: (1) the types of clubs that are active in the schools, (2) the most common types of clubs and (3) their representation in Osijek primary and secondary schools. Then, based on informational semi-structured interviews and active observation, the work of 21 extracurricular clubs related to Croatian language and literature teaching is described and analysed in an attempt to determine to which extent the clubs influence the literary, poetry recitation, drama, journalist and film related creative work of students.

The research revealed that clubs in the focus of research were very popular in primary and secondary schools in Osijek, especially literary, poetry recitation, drama and journalist clubs. More importantly, it was shown that they do foster student creativity which was confirmed by the concrete examples in practice, i.e. students' creative results.
\end{abstract}

Keywords: literary clubs, poetry recitation and drama clubs, journalist clubs, film clubs, student creativity

\section{Introduction}

\subsection{School Clubs as an Incentive in Fostering Student Creativity}

The young spend a significant amount of time in school and therefore the school has an important role in the development of an individual, which cannot be ignored. The efforts to overcome the limitations of regular class teaching are various, and one of them is to organise extracurricular clubs. The students participate in the clubs on the principle of self-selection and voluntarism, which is a prerequisite for active involvement in any type of work. By taking part in the clubs, students connect with the society, i.e. the reality, too (Geršić, 1974: 88).

As a part of the educational process, the Croatian language and literature teaching related clubs play a major role in fostering student creativity. All students are potential creators and should be encouraged and guided to develop their creative abilities. The clubs serve as a fertile ground for the development of creative work as they are subject to minimum authoritarian requirements of the curricula or textbooks. Moreover, the work in the clubs provides for a more intimate and friendly relationship between the coordinators and the students, the students feel free and are more active in the organization and implementation of club activities, and they also learn without fear of mistakes or grading (Previšić, 1987).

The literary, poetry recitation and drama, journalist (radio) and film clubs, although well represented in primary and secondary schools, have not been adequately explored in scientific literature on the Croatian language and literature related clubs, which poses a problem in the organization and management of their work. Težak's manual Literary, journalist, recitation and related clubs (1979) and the book by Previšić Extracurricular activities and creativity (1987), methodological literature analysing ways and methods of teaching students in extracurricular clubs, are of older date. 
Nevertheless, two books confirm that efforts have been invested in rectifying the problem: the manual The first school play by V. Dresto and A. Bosanac from 2007, designed for beginners as drama club coordinators in primary schools, and Journalism at school by B. Primorac, M. Šimeg and A. Šojat, a manual published in 2010, which contains many useful tips for the efficient work of a journalist club. However, what about literary, recitation, radio and film clubs? The lack of professional and methodological literature also indicates the lack of professional qualifications of young teachers, club coordinators, who do not acquire the knowledge required for guiding clubs at the university level either, which has a negative impact on the creative work of the clubs.

In this regard, the research aimed to investigate the way in which Croatian language and literature related clubs are approached today, and whether they foster creativity among students.

\subsection{Significance of Research into the Work of Extracurricular Clubs}

Pedagogical, didactic and methodological solutions for the training of teachers and students for creative work can be sought by linking the theory of creativity, determined by novelty, originality and uniqueness, and the standards of the creative process with the features of extracurricular activities. Without doubt, such theoretical framework is essential for practical work.

The lack of methodological literature on the organization and management of literary, recitation (poetry and drama), journalism (radio) and film clubs, as well as the insufficient training of young teachers as club coordinators indicate the need for studying contemporary real situations prevailing within the clubs. The research results can help club coordinators who are beginners, and who do not have sufficient knowledge and experience in setting up and running literary, poetry recitation, drama, journalist, radio and film clubs. In addition to the fact that they cannot acquire the required expertise at universities, they cannot find support in methodological literature either, as this area has been insufficiently discussed in professional literature on Croatian language and literature teaching related clubs. All in all, personal qualities of teachers as coordinators and their expertise are essential for the success of a club. Further, the research can detect to what extent creativity can be represented in club activities, and it can also offer helpful tips and examples of choosing specific working methods that create favourable conditions for boosting student creativity. In a broader context, another aim of the research is to encourage pedagogical, didactic and methodological experts to produce manuals on guiding extracurricular clubs related to Croatian language and literature.

\subsection{Brief Overview of Literature}

\subsubsection{Creativity and the Creative Process}

There have been many attempts at defining creativity; nevertheless, there is a common ground among the different theoretical concepts. Creativity is determined by novelty, originality, ingenuity and inventiveness (Mihailovič Teplov, 1950; Stevanović, 1961; Kvaščev, 1974; Vukasović, 1976; Poljak, 1978; Karlavaris \& Kraguljac, 1981; Mlinarević \& Brust Nemet, 2012), flexibility in abandoning the stereotypical way of problem solving, adjustment to new requirements and working methods, fluency of ideas and associations, the ability to interpret familiar concepts in a new, unusual way, the ability to identify and address gaps in phenomena for the purpose of correcting them and arriving at more original solutions, the ability to develop a plan to solve a problem (J. P. Guilford, 1959: 143-161), the desire for progressive altering of reality people come into direct or indirect contact with (Filipović, 1969: 18), risk taking (Mlinarević \& Brust Nemet, 2012: 171), the sense of what is important, imagination and organization (Karlavaris \& Kraguljac, 1981: 12).

Creativity does not only imply the original final result of work, but also the time-consuming process with specific stages that can be monitored in the case of students. According to the conclusions set by Previšic (1987: 62-75) these are the following stages which are mentioned by most scholars: a) preparation, b) productive creative thinking operations and c) the creative result. The period of preparation involves investing knowledge, experience and activities in problem solving (Previšić, 1987: 75), which is impossible without knowing what has already been done in theory and practice in a particular area (Poljak, 1987: 38). The central stage refers to the productive creative thinking operations in which an individual thinks freely, combines, makes mistakes and discovers, and the creative result is something new, original and unique (Previšić, 1987: 52). The final phase of the creative process is the release of the creative result to the public by which it gains social meaning and value (Poljak, 1987: 52).

\subsubsection{Conditions for Developing Creativity in Extracurricular Clubs}

Professional literature on extracurricular activities agrees that they provide space for the organization and implementation of creative work more successfully than the regular teaching process.

In other words, one of the most important conditions conducive to creative work is the relationship between the club coordinator and the students. On the one hand, the coordinators initially drive the work of the club (Fudurić, 2012: 108), but later become an equal partner and even a friend to the students. On the other hand, the students do not see the 
coordinators as authority anymore, but cooperate with them in running the club and release their self-management potentials. Moreover, the friendly relationship between the club coordinators and the students has a positive effect on the club environment and the atmosphere - no usual roll-calls, the meeting begins with a relaxed conversation, the students sit facing each other without the classic classroom rows and columns, there is no grading at the end of the activity, no bell is heard, there is only the freedom of creation (Previšić, 1987: 98-100). An environment conducive to the development of creativity is also created by the engagement of students in a club on the principle of self-selection, which is a precondition for a more active involvement in the work, individualized work that can be closely monitored and student engagement in reality by meeting their desires and creative needs (Geršić, 1974: 88-89). Lastly, the open and variable work plan and program, in the creation of which students can participate as well, constitute an organisational advantage for boosting creativity in the clubs (Previšić, 1987: 40).

\subsubsection{Work in Literary, Poetry Recitation, Drama, Journalist and Film Clubs}

The methodological literature on the work of Croatian language and literature related clubs is of older date.

In the journal Life and School: A Journal of Theory and Practice of Education a few articles like Z. Nemet's Examples of literary club activities (1969), N. Munitić's Working with a poetry recitation club (1972), and Lj. Vojvodić's In search of more successful performance of literary clubs (1972) dealt with clubs related to Croatian language and literature. Težak's manual Literature, journalism, poetry recitation, drama and related clubs is a sort of a textbook on the work of literary, poetry recitation, drama, journalist and film clubs or, as the author says: 'a practical guideline that lists the possibilities and, thereby, encourages teachers to use and develop them according to the given circumstances' (1979: 281); however, it was published back in 1979. Further, Previšić's book Extracurricular activities and creativity, also published back in 1987, is focused on extracurricular activities in general, so it illustrates just a touch of clubs which were the focus of this research. At the end of the book Film Teaching Methodology at General Educational Level, published in 2002, S. Težak dedicated some space to the work of film clubs as well. The book 100+ideas for a drama play by A. Scher and C. Verralla in 2005, and The first play: a manual for beginners as drama and theatrical club coordinators in primary schools by V. Dresto and A. Bosanac from 2007 have contributed to the work of drama clubs. Journalism in school by B. Primorac, M. Šimega and A. Šojat from 2010 is a textbook with detailed instructions on working with journalist clubs.

Although the above books and articles are valuable sources of guideline on how to manage a club, the novelties that emerge on almost a daily basis in schools require a more modern and more comprehensive approach to this area, especially in the case of radio and film clubs.

\subsection{Hypotheses}

The best way to study the work of literary, poetry recitation and drama, journalist, radio and film clubs is field work, i.e. active observation of club activities in schools on the basis of which one can explore the contemporary approaches to the work of clubs and conclude what their role in fostering creativity among students is. Therefore, based on concrete examples in practice, the article aims to illustrate the ways in which the clubs operate today, and to what extent their work can influence the creative processes of students.

In order to address this problem, it is necessary to study the school curricula of primary and secondary schools first to determine the (non)representation of extracurricular clubs in Croatian language and literature teaching. The initial hypothesis was that the clubs related to the teaching of Croatian language and literature are very popular among students in primary and secondary schools, even more so in primary schools, due to the wider area of teaching they are focused on. Consequently, if they are popular, a study of the significance of the impact of the clubs on student creativity has reasonable foundations. When it comes to the types of clubs, due to financial and technical constraints, it was expected that literary, poetry recitation, drama and journalism clubs are more popular than film and radio clubs.

\section{Research Method}

The research was divided into two parts. The first part of the research included the review of the 2014/2015 school curricula of primary and secondary schools in Osijek in Croatia, with the aim of obtaining the following information: (1) whether literary, poetry recitation, drama, journalist, radio and film clubs are represented in practice; (2) what types of clubs can be found in practice, and their overview by schools; (3) the most common types of clubs in practice (4); whether the clubs are represented in Osijek primary or secondary schools; (5) which primary or secondary school stands out for the highest number of active clubs.

After having determined the presence of clubs in practice by reviewing school curricula, the second part of the research concerned the comparison of theory and practice. The working methods of individual literary, poetry recitation, drama, journalist, radio and film clubs in practice were studied, as well as their impact on the development of creative abilities of students in Osijek primary and secondary schools. 


\subsection{Participants}

The focus of the study were the Croatian language and literature related extracurricular clubs in primary and secondary schools in the city of Osijek. In the case of primary schools, only the clubs involving fifth grade students and above were taken into consideration. In secondary schools, the research included grammar schools (gymnasiums) and vocational schools. The participants were members of the clubs of both gender, and the club coordinators.

\subsubsection{Review of 2014/2015 School Curricula of Osijek Primary and Secondary Schools}

In the first part of the research, the review of 2014/2015 school curricula included 16 primary and 15 secondary schools in Osijek.

The primary schools (PS) were as follows: Antun Mihanović, August Šenoa, Dobriša Cesarić, Fran Krsto Frankopan, Franjo Krežma, Grigor Vitez, Ivan Filipović, Center for Education Ivan Štark, Jagoda Truhelka, Ljudevit Gaj, Mladost, Retfala, St. Ana, Tin Ujević, Vijenac and Vladimir Becić.

The following secondary schools were covered by the research: the Vocational School of Economics, Electrical Engineering and Traffic School, Civil Engineering and Geodesy School, First Grammar School, Second Grammar School, Grammar School of Natural Sciences and Mathematics, Jesuit Classical Gymnasium in Osijek, Medical School, Crafts School, Agricultural and Veterinary School, Mechanical Engineering Technical School, School of Art and Design, Technical School and Ruđer Bošković Natural Sciences Grammar School, Davor Milas Trade and Commercial School and Hospitality and Tourism School.

2.1.2 The Analysis of Club Activities and the Role of Clubs in Fostering Student Creativity

The working methods of Croatian language and literature teaching related clubs and their impact on the development of students' creativity was studied in 8 primary and 13 secondary schools, i.e. a total of 21 clubs.

Overall, the research included the work of:

- two literary clubs (Lj. Gaj PS and the Second (Language) Grammar School in Osijek)

- two poetry recitation clubs (V. Becić PS and the Vocational School of Economics)

- three drama clubs (Technical School and Ruđer Bošković Natural Sciences Grammar School, Civil Engineering and Geodesy School and Hospitality and Tourism School)

- five journalist clubs (D. Cesarić PS, Retfala PS, Jesuit Classical Grammar School, Medical School and Hospitality and Tourism School)

- two radio clubs (Second Grammar School and Medical School)

- three film clubs (F. Krežma PS, T. Ujević PS and Medical School)

- one literary and theatrical club (F. Krežma PS)

- a readers' and journalist club (F. K. Frankopan PS)

- a literary and drama club (Mechanical Engineering Technical School)

- poetry recitation and drama club (Medical School).

\subsection{Data Collection and Analysis}

The 2014/2015 school curricula were downloaded from the official web site of Osijek schools included in the research. The first part of the research was based on the following methods: reading the chapter on Croatian language and literature related extracurricular activities in school curricula, extracting data on the type and number of clubs and determining the names and surnames of the club coordinators. For the purpose of clarity, the research results are presented in Tables 1, 2 and 3 (Chapter 3).

Having established which clubs were organized in 2014/2015 and in which schools, their coordinators were contacted. It was impossible to simultaneously monitor the work of the clubs in all of Osijek schools, mainly due to the overlapping timings of club meetings and the spatial distance of the schools, but also due to the lack of willingness to cooperate by some coordinators. In the period from late January to mid-June 2015, active live monitoring and/or interview-based research was conducted on the work of 21 clubs in Osijek primary and secondary schools. To be more precise, the period of monitoring the work of individual clubs varied, except for the literary and drama club of Franjo Krežma PS, whose work was actively monitored once a week in the mentioned period.

In this context, active monitoring was applied to 8 clubs, whereas the information on the work of the remaining 13 clubs was obtained in the semi-structured interviews conducted with the coordinators and club members. Interestingly, the monitoring of the work of clubs included more clubs of the same type which allowed the comparison of their work in 
the same area at the same or different educational level of schooling.

In the conducted semi-structured interviews, the basic information about the clubs were noted down: the name, surname and years of experience of the club coordinator, the number of club members, the plan and work program, the usual mode of operation and the description of the creative process in 2014/2015.

It is important to note that the clubs and their coordinators were informed about the purpose of the research, but at no point was the work of the club manipulated; they were relaxed and spontaneous in creating in their natural environment.

In the end, after the monitoring and active participation in meetings and semi-structured interviews with the coordinators and the members of the clubs, the data on their operation with a focus on the ongoing creative processes involving the students were systematically recorded, and the students' literary works, drama plays and newspaper articles, photos and videos of their work were collected.

\section{Results}

This chapter answers the question whether literary, poetry recitation, drama, journalist (radio) and film clubs were represented in Osijek primary and secondary schools in the school year 2014/2015, what types of clubs were most represented with their overview per schools, whether they were represented in Osijek primary or secondary schools and, finally, whether any of the Osijek schools stand out by the number of active clubs.

Having determined the presence of the clubs in practice, the features of the creative process in individual clubs were determined and conclusions were drawn as to what extent their work can affect the development of the creative abilities of students.

\subsection{Analysis of the Results of Research of School Curricula of Primary and Secondary School in Osijek}

The study of the 2014/2015 school curricula of Osijek primary and secondary schools confirmed all types of Croatian language and literature related clubs which were the focus of the research, i.e. literary, poetry recitation, drama, journalist, radio and film clubs, either as independent clubs, or as a combination of two types of clubs.

The clubs that are actually a combination of two different types are listed in both types of clubs in Table 1, but are counted as one. These are the readers' and journalist club of F. K. Frankopan PS, the drama and literary club of G. Vitez PS, the drama and poetry recitation club of T. Ujević PS, the poetry recitation and drama club of the Medical School and the literary and drama club of the Mechanical Engineering Technical School. A particular example is the journalist club of D. Cesarić PS. In fact, there are two different clubs within the journalist club - the journalist club (deals with creating the printed school newspaper) and the web journalists. They have different coordinators and were counted separately. 
Table 1. Overview of Croatian language and literature related clubs in primary and secondary schools in Osijek in the school year 2014/2015.

\begin{tabular}{|c|c|c|c|c|c|c|c|}
\hline School & Literary & Poetry Recitation & Drama & Journalist & Film & Radio & Total \\
\hline 1. Antun Mihanović & + & - & - & + & - & - & 2 \\
\hline 2. August Šenoa & + & - & + & - & - & - & 2 \\
\hline 3. Dobriša Cesarić & - & - & + & + & - & - & 3 \\
\hline 4. Fran Krsto Frankopan & - & - & + & + & - & - & 2 \\
\hline 5. Franjo Krežma & + & - & + & + & + & - & 4 \\
\hline 6. Grigor Vitez & + & - & + & + & - & - & 2 \\
\hline 7. Ivan Filipović & + & - & + & - & - & - & 2 \\
\hline 8. Ivan Štark & - & - & + & + & - & - & 2 \\
\hline 9. Jagoda Truhelka & + & - & - & + & + & - & 3 \\
\hline 10. Ljudevit Gaj & + & - & - & - & - & - & 1 \\
\hline 11. Mladost & - & - & - & + & - & - & 1 \\
\hline 12. Retfala & - & - & - & + & - & - & 1 \\
\hline 13. St. Ana & + & - & - & - & - & - & 1 \\
\hline 14. Tin Ujević & - & + & + & - & + & - & 2 \\
\hline 15. Vijenac & - & + & - & - & - & - & 1 \\
\hline 16. Vladimir Becić & + & + & - & - & - & - & 2 \\
\hline $\begin{array}{l}\text { 17. Vocational School of } \\
\text { Economics }\end{array}$ & + & + & - & + & - & - & 3 \\
\hline $\begin{array}{l}\text { 18. Electrical Engineering and } \\
\text { Traffic School }\end{array}$ & - & - & + & - & - & - & 1 \\
\hline $\begin{array}{l}\text { 19. Civil Engineering and } \\
\text { Geodesy School }\end{array}$ & + & - & + & - & - & - & 2 \\
\hline 20. First Grammar School & + & + & + & + & - & - & 4 \\
\hline $\begin{array}{lll}21 . & \text { Second } & \text { Grammar } \\
\text { School } & & \end{array}$ & + & - & + & + & - & + & 4 \\
\hline 22. Third Grammar School & + & - & + & + & - & - & 3 \\
\hline $\begin{array}{l}\text { 23. Jesuit Classical Grammar } \\
\text { School }\end{array}$ & - & - & + & + & - & - & 2 \\
\hline 24. Medical school & + & + & + & + & + & + & 5 \\
\hline 25. Crafts School & - & 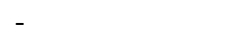 & + & + & - & - & 2 \\
\hline $\begin{array}{l}\text { 26. Agricultural and } \\
\text { Veterinary School }\end{array}$ & - & - & + & - & - & - & 1 \\
\hline $\begin{array}{l}\text { 27. Mechanical Engineering } \\
\text { Technical School }\end{array}$ & + & - & + & + & - & - & 2 \\
\hline 28. School of Art and Design & + & - & - & - & + & - & 2 \\
\hline $\begin{array}{l}\text { 29. Technical School and } \\
\text { Ruđer Bošković Natural }\end{array}$ & - & + & + & - & - & - & 2 \\
\hline Sciences Grammar School & & & & & & & \\
\hline $\begin{array}{l}\text { 30. Davor Milas Trade and } \\
\text { Commercial School }\end{array}$ & - & + & + & + & - & - & 3 \\
\hline 31. Hospitality and Tourism & + & + & + & + & - & - & 4 \\
\hline
\end{tabular}

As shown in Table 1, in every primary and secondary school in Osijek at least one Croatian language and literature related club was active in the school year 2014/2015. In most schools, 14 of them, there were two active clubs of different types. However, seven schools organized (only) one club. The Medical School is the only one among Osijek primary and secondary schools in which all club types that are the focus of the research were active. By the number of different types of clubs, Medical School was followed by F. Krežma PS, the First Grammar School, the Second Grammar School and the Hospitality and Tourism School with a total of 4 different types of clubs.

Table 2. List of Croatian language and literature related clubs and the number of primary schools in which they were active in the school year 2014/2015

\begin{tabular}{lc}
\hline \multicolumn{1}{c}{ NAME OF CLUB } & NUMBER OF SCHOOLS \\
1. Literary Club & 9 \\
2. Poetry Recitation Club & 3 \\
3. Drama Club & 8 \\
4. Journalist Club & 9 \\
5. Radio Club & 0 \\
6. Film Club & 3 \\
TOTAL & 32 \\
\hline
\end{tabular}


Table 3. List of Croatian language and literature related clubs and the number of secondary schools in which they were active in the school year 2014/2015

\begin{tabular}{lr}
\hline \multicolumn{2}{c}{ SECONDARY SCHOOLS IN OSIJEK (2014/2015) } \\
NAME OF CLUB & NUMBER OF SCHOOLS \\
1. Literary Club & 9 \\
2. Poetry Recitation Club & 6 \\
3. Drama Club & 13 \\
4. Journalist Club & 10 \\
5. Radio Club & 2 \\
6. Film Club & 2 \\
TOTAL & 42 \\
\hline
\end{tabular}

Table 2 and Table 3 identify the most common types of clubs organized in primary and secondary schools, and whether they were more prevalent in primary or secondary schools. As shown in the tables, in 2014/2015 there were 32 active clubs in primary schools in Osijek, and 42 in secondary schools. In other words, there were more clubs organized in secondary than in primary schools.

Table 2 shows that the predominant clubs in primary schools were literary and journalist clubs with the same number of primary schools where they were active, i.e. nine clubs. They were followed by drama clubs that were organized in eight primary schools in Osijek. Poetry recitation and film clubs were organized in three schools, whereas radio clubs were not organised as a separate club in any of the schools.

According to the data in Table 3, in secondary schools, i.e. in 13 of them, drama clubs were the most frequent ones. Journalist clubs were organized in 10 secondary schools, literary clubs in nine, and poetry recitation clubs in six secondary schools in Osijek. The least frequent clubs in secondary schools were film and radio clubs, and they were active in only two schools.

The conclusion that can be drawn by comparing the frequency of certain types of clubs in Osijek primary and secondary schools is that the most popular ones were literary, poetry recitation, drama and journalist clubs, while there was only a lower number of radio and film clubs.

\subsection{Analysis of the Work of Literary, Poetry Recitation, Drama, Journalist, Radio and Film Clubs and Their Role in Encouraging Student Creativity in Practice}

\subsubsection{The Stage of Development of the Preconditions for Student Creativity in Practice}

As a result of active monitoring, research and informational semi-structured interviews with the coordinators and members of 21 clubs in Osijek primary and secondary schools, it can be concluded that the studied clubs serve as positive examples of their influence on student creativity. The success of the clubs, whose high quality results have been recognized in a number of competitions and festivals in Croatia, are a result of cooperation between the students and the club coordinators. As regards the coordinators, it should be stressed that they are teachers with year-long experience who had to rely on themselves at the beginning of their work, and who perfected their skills by attending workshops and seminars and learned through experience and from their own mistakes.

By comparing the clubs of the same type, the conclusion drawn is that the creative processes taking place in them were developing in a similar way as they were aimed at the same goals. To be more specific, the studied clubs developed favourable conditions for the development of students' creativity, which confirms that the work of the clubs in practice is in compliance with the theoretical concepts postulated in the literature on extracurricular activities. Firstly, there was a predominantly spontaneous and working atmosphere in the clubs and the students were the carriers of activities. Secondly, students were unencumbered by formal rules and they freely applied their knowledge, developed work plans, researched and discovered, spontaneously proposed original ideas, i.e. solved problems without fear of mistakes and felt satisfaction in the results of their involvement. Thirdly, the studied clubs did not strive to shape future artists; they were aimed at deepening the students' knowledge and the development of their abilities and skills, depending on the type of club. Finally, the results of work were original and unique, which is a characteristic of creativity.

When comparing the work of clubs of the same type in primary and secondary schools, the conclusion is that high school students were taking over greater responsibility and activity in the tasks than the students in primary schools. This difference was most strongly felt in journalist, radio and film clubs. For example, in primary schools, the journalists created by conducting research and writing news accompanied by photos or illustrations, whereas the journalists in secondary schools acted a step forward and participated in the graphic design of the school newspaper; in primary schools, this was done by the club coordinators. In a similar way, the students in radio and film clubs in secondary schools were the ones who recorded and edited radio shows or movies, whereas in primary schools, this role was assumed by the club coordinators. However, there are some exceptions. In primary schools the students who make 
movies outside of school edited the films for their respective clubs.

As far as all the clubs related to Croatian language and literature are concerned, the literary clubs stand out due to the inconsistency between their envisaged place in the proposed school curriculum and the actual work of literary clubs in practice. To put it differently, although the study of school curricula showed that there were a total of 18 organized literary clubs in Osijek primary and secondary schools, two clubs of this type are barely found in practice. The research has revealed that a large number of literary clubs exist only 'on paper', i.e., they do not exist as clubs that hold regular meetings. Thus, the results of creative work frequently occur in regular Croatian language and literature classes or at home. One of the arguments used by the teachers to justify the situation in practice is that there is no need for meetings, because students cannot be forced to create in a concrete given moment and a given time, but that literary works are created only when the students feel inspired.

It is important here to point out that the literary clubs are much more than the act of creating literary masterpieces, which is confirmed by the literary club of $\mathrm{Lj}$. Gaj School in Sarvaš. The literary club members from Sarvaš are an example, as evidenced by the description of one of their meetings below, that literary clubs provide the club coordinator an abundance of forms and methods of work and activities that affect the development of students' critical thinking, oral and written creative expression.

A meeting of the literary club of Lj. Gaj PS led by teacher Zvjezdana Sikra-Golemac (25 March 2015)

Activity 1: The students pick pieces of paper with the title of a fairy tale (e.g., Cinderella, Sleeping Beauty, Peter Pan, The Little Mermaid, The Ugly Duckling, etc.). Their task is, based on their knowledge of the fairy tales, to describe the fairy tale in ten words. The words should be key words for the picked fairytale (e.g. Cinderella step-mother, maid, good fairy, dress, pumpkin, mice, coach, ball, glass slipper, prince). The other students have to guess the fairy tale.

Activity 2: The students imagine an indoor space from the picked fairy tale and orally present their choice (e.g. the grandmother's house, the deck, castle, children's room, etc.).

Activity 3: The students repeat how to write a description of the interior.

Activity 4: The students describe the interior of the selected fairy tale in writing.

Activity 5: The students read what they have written and comment on each other's descriptions (point out the positive and negative sides).

Activity 6: The students imagine they are in the world of the fairy tale they have picked. They choose by themselves the part of the plot they appear in, and how they have changed the further course of action. The students orally present the results.

Activity 7: Circle story. One student says the initial sentence, the next one continues the story by building on the previous sentence, and so on in a circle.

\subsubsection{Creative Process}

Although each of the 21 clubs studied is special and original, the creative process in them took place in a similar way as they were aimed at the same goals.

\subsubsection{Literary Clubs}

In the literary clubs of Lj. Gaj Sub-school and the Second Grammar School, the creative process started by learning about literary theory, i.e. by deepening literary knowledge. After the members of the club selected the topics on their own, their literary works were read several times, analysed, revised and edited. All the members participated in the analysis and the editing by offering each other advice. It is important to note that there were no immediate rough corrections of the works; the students' attention was first drawn to the weaker parts of the literary piece in order to give them a chance to find a better solution themselves. However, the difference between the two clubs is in the final stages of the creative process. The literary club members of Lj. Gaj Sub-school presented the results of their creative work only before the club members club, whereas the literary club of the Second Grammar School participated at festivals, such as LiDraNo or Goran's Spring, and presented the results of their literary art work to a wider audience.

\subsubsection{Poetry Recitation and Drama Clubs}

The study of practice has shown that the recitation clubs, due to a close link in the content of their work with drama clubs, often do not stand out as separate clubs. In both types, following the adoption of the basic theory of poetry and theatre arts, the dramatic expression of the students was encouraged through exercises and improvisations.

The sequence of work in the recitation clubs of V. Becić PS and the Vocational School of Economics was as follows: preliminary exercises, selection and analysis of the text to be recited, practicing reading the selected text, learning the 
text by heart, organising the recital, recital rehearsal, public appearance. In both clubs it was essential that the students themselves selected the text they liked, because it was an indication that they had experienced it. Also, by practicing reading the texts, the members showed that they understood the main features of the literary text which helped them in determining the rhythm and intonation, proper intake of breath, expressing a sense of softness or harshness of voice.

On the other hand, in the studied drama clubs the central stage of the creative process began by creating the text of a play. The drama clubs of the following schools were creating at a higher level by inventing the play on their own: $\mathrm{F}$. Krežma PS, Medical School, Mechanical Engineering Technical School and the Technical School and Ruđer Bošković Natural Sciences Grammar School. In this context, the exception of the studied drama clubs in Osijek is club of the Civil Engineering and Geodesy School which prepared a play based on a literary template Bucka (Chubby) by Janja Vidmar, but that does not diminish its value. Although the texts of the plays of the studied clubs originated from before the reading rehearsals, the texts were not final. In other words, during the rehearsals, new parts were included and the old parts were amended or supplemented, the order of the actors' performances was changed, new actors were included and roles were changed. All the members worked equally and tailored the text according to their own interests. The casting in the clubs was spontaneous. The club members were free to choose the roles or the roles were distributed amongst themselves after several readings. After the casting of the parts, the reading rehearsals and the analysis of the characters and the atmosphere, the drama was rehearsed on stage. The clubs showed creativity in designing the costumes and the scene too.

The creative process of studied drama clubs ended up with presenting the original results of their work to the public. The school performance Bucka, with which the Civil Engineering and Geodesy High School participated at the 2015 state level LiDraNo competition in Croatia, highlighted the obsession of the youth with external appearance and the problems of bulimia and anorexia by the game of shadows, facial expressions and small changes to the body. The performance of the Medical School drama club 'People in the world do not know what recession is' presented in a humorous way their vision of politics and the current problems in Croatia. The 'Actors' of the Mechanical Engineering Technical School presented high school scenes in a humorous way by staging a typical homeroom class session and a class of Croatian language and literature. The drama club of the Technical School and Ruđer Bošković Natural Sciences Grammar School created a performance for the Easter school event.

\subsubsection{Journalist Clubs}

In the studied journalist clubs, in the preparatory stage the members were introduced to news types and the rules of writing news articles. The central stage of the process started by searching for ideas (themes) for a text and then they began working on the text. Writing was preceded by preparation, interviews, observation, reflection and research in order for the journalist to understand the subject matter, and then convey it to the readers. After having collected data on the chosen topic, they selected the news type. The journalist wrote a first draft of the text, and then submitted the final version to the editor - who assessed whether or not the text required editing. Once the text was marked as finalised, it was published. The journalists in secondary schools showed creativity in designing the pages of the newspaper too - the layout of the cover and the last page, they selected the type and size of the font for the body of the text, the heading, the titles, the authors of the text and signatures under the photos, selected the photos and illustrations as well as their placement in space, the selection of the appearance and the colour of the titles and headings. The works of the journalists in D.Cesarić and F. K. Frankopan Primary School, the Jesuit Classical Grammar School, the Medical School and the Hospitality and Tourism School were collected in the school newspapers which were eventually printed. Even though their creative processes are very similar, the journalist club of Retfala Primary School differs from other clubs in the fact that for the past five years they have focused on digital editing of their school paper, and not a printed version.

\subsubsection{Radio Clubs}

There were no major differences in the work of the radio clubs of the Second Grammar School and the Medical School in Osijek. The achievement of the objectives set by the studied clubs began by their preparation for creative work. Having adopted the basic concepts and having learned about the theoretical background of creating a radio show, the club members chose their topic. In their choice of topics, both clubs were looking for topical and interesting themes. In 2014/2015 on the one hand the Second Grammar School recorded a show It is difficult with it, and without it even harder trying to answer the question whether cell phones are a help or hindrance to young people, due to the fact that many cannot imagine their lives without this medium. On the other hand, the Medical School club dealt with the fear of public speaking in a radio show Do not ask me, tackling not only public appearance on the stage, but public appearance of any type - oral exams, oral presentations in schools or interviews. The clubs were creating the structure of a radio show by coming up with declarative and interrogative sentences and thinking about the participants in the survey and the interviews. After the creative work on the rough outline of the text of a radio show, they started with the arrangements and the distribution of tasks and responsibilities in accordance with the student's interests i.e. developed 
the work plan. After independent research work on data collection, the club members jointly listened to and commented on the recorded material, identified the deficiencies and corrected them, cut and edited the parts of the show, incorporated music, i.e. edited a radio show. The last stage of the creative process was the broadcasting of the radio show. The Medical School club took part in the 2015 LiDraNo competition at state level in Croatia with their radio show.

\subsubsection{Film Clubs}

The main objectives of the three studied film clubs were to familiarise the students with the film production process and to train them in making films. The film club of F. Krežma PS focused on making short films, and the film club of the Medical School mostly filmed documentaries by participating in projects, festivals and shows, while the T. Ujević Primary School club created a love-themed musical feature film.

That the work in the studied film clubs has an impact on students' creativity is shown on the example of the creative process of the F. Krežma PS film club. The work of the club in 2014/2015 was marked by the creation of the film Hello, I'm a zombie with which they participated in the central event 'The first multimedia festival of health - Against Addiction' held at Mladost PS on 12 December 2014. Although the theme of the film was given, creative work was not missing. The creative process began with a discussion about addictions and brainstorming about the content of the film, and the ideas were written on the blackboard. The students adapted to the given topic, conducted research, proposed, debated - in other words, created. Together, with the coordinator's guidance, they came up with the idea that the film should recount several parallel stories describing the different types of addiction in the form of news reports. They covered contents appropriate for the student's age: addiction to coffee, violence, cigarettes, adhesives, food and games. The idea of students who turn into zombies due to addiction derives from many books, TV series and films about zombies, which have become increasingly popular today. One student wrote the screenplay for the film, according to the ideas presented by the club. It was followed by reading the text aloud with amendments and final editing. After working on the text, the roles were assigned according to the interests and wishes of the students. The imagined scenes were initially performed without make-up and props in order to help the students relax and get into their roles. The members of the film club agreed on the shooting location, most of which were school premises, on the makeup and the costumes that were made by using the do-it-yourself method. Having determined the tasks of each member of the club, the main scenes were filmed. Prior to the final cut and editing, the so-called 'pick-up shots' had to be made for a smooth transition to connect all the scenes into one unit, e.g. the school hall, a classroom desk. Although the students were familiarised with the theoretical background of how to edit a film, due to time constraints, the teacher L. Pejić edited the film on his own. The whole process of filming was completed by the screening of the film for which they received acclaim.

\section{Discussion and Conclusion}

A review of the school curricula of Osijek primary and secondary schools revealed that in the school year 2014/2015 all types of clubs related to Croatian language and literature teaching were active. Contrary to the postulated hypothesis, the results showed that there were more clubs related to Croatian language and literature teaching organized in secondary schools than in primary schools. The difference in numbers is not large, 42 to 32 , but the data are surprising, all the more so as out of the 15 secondary schools in Osijek, which were the focus of the research, as many as 11 of them are vocational schools that are focused on specific areas of training students for vocational careers.

With regard to individual types of clubs, according to the hypothesis, the most popular are the literary, poetry recitation, drama and journalist clubs, while there is a lower number of radio and film club. The causes of this are of material and technical nature: for example, the lack of technical equipment and complex processes of creating radio shows and films. In addition, the radio clubs do not attract young people as the other types of clubs do, due to the fact that radio is not a popular medium among young people. Although the review of school curricula determined a significant number of literary clubs, the practice has shown that a large number of them exist only formally as many neglect the fact that the work of a literary club covers much more than the mere creation of literary works.

It is interesting to note that the Medical School is the only one of Osijek primary and secondary schools which organized all types of clubs that are the focus of this research. The data is interesting because it is, in fact, a vocational school whose main mission is to educate students in the field of health. The school has thus shown a positive attitude towards the acquisition of knowledge in areas that are not closely related to its main mission.

The second part of the study was the analysis of the literary, poetry recitation, drama, journalist, radio and film clubs in practice. The study of creativity within these clubs has shown that they can influence the creative work of students at a very high level which was confirmed by the results of their work. The studied clubs created literary works, recitals and plays, edited and printed school newspapers and created radio shows and films. 
Although the steps of the creative process of certain types of clubs can be put into a sentence, it is a long, challenging and difficult journey to achieve original and unique results. Moreover, a more complex creative process took place in the secondary school clubs than in primary school clubs, which is in accordance with the differences in the students' abilities. This difference is most evident in journalist, radio and film clubs, which, unlike the literary and poetry recitation and drama clubs, imply the application of technical knowledge in their work such as computer literacy or work with a recorder and a camera. During the creative process in the studied clubs, the members contemplated, proposed, evaluated, elaborated work plans, identified the pros and cons of their ideas and corrected them, anticipated, discussed, analyzed, shaped, and the entire process was marked by originality. In other words, work in studied clubs did foster student creativity.

In a broader context, the aim of the research was to contribute to the unexplored methodological themes of the organization and management of extracurricular literary, poetry recitation, drama, journalist, radio and film clubs that are poorly represented in literature on Croatian language and literature teaching. It also sought to emphasize that the extracurricular activities are very important and not an insignificant part of the educational process. In other words, they open up the possibility for a different way of work than regular classes, for a closer relationship between the club coordinator and the students and for open and free student behaviour. Furthermore, the clubs are incentives for troubleshooting and for the liberation from the authoritative requirements of the official work plans and programs or working with a textbook. These are all conditions that are conducive to the development of creativity, which has been confirmed in practice when describing creative processes of individual types of clubs.

The research has some limitations. Of course, the studied extracurricular literary, poetry recitation, drama, journalist and film clubs of Osijek primary and secondary schools in the school year 2014/2015 are isolated cases of positive impact on the development of the creative abilities of students. But, at the same time, they are a good example and an encouragement for (future) club coordinators. They also serve as an incentive to the pedagogical, didactic and methodological experts to create a manual on the management of the above mentioned clubs. The lack of methodological literature on Croatian language and literature related clubs with practical guidelines is partly the cause of the lack of qualifications of young teachers as club coordinators, and this has a negative impact on the creativity of students. In order for education in Croatia to achieve progress in this area, it is undoubtedly necessary to start solving such unavoidable problems of the entire education system.

\section{Acknowledgements}

Special thanks to the following club coordinators for their good will, kindness, friendly mood and assistance: Zvjezdana Sikra-Golemac, Marija Kalić, Snježana Laksar, Marinko Plazibat, Luka Pejić, Slavica Šakić Matić, Ivana Rašić, Andrea Katavić, Kristina Inhof, Marija Luc, Snježana Šulentić, Stela Macakanja-Baćić, Marko Ek, Vera Bilandžić, Alta Pavin Banović, Lucija Rebrina, Mirjana Bogdanović, Marina Pilj Tomić, Đurđica Radić, Mirna Bence-Milić, Inga Čunović, Mirta Faktor and Vesna Kasač.

\section{References}

Dresto, V., \& Bosanac, A. (2007). Prva predstava: priručnik za voditelje početnike dramsko-scenskih skupina u osnovnoj školi. Zagreb: Naklada Ljevak.

Filipović, N. (1969). Stvaralaštvo u nastavi. Sarajevo: Zavod za izdavanje udžbenika.

Fudurić, B. (2012). Mogućnosti rada u izvannastavnoj aktivnosti. Napredak, 153 (1), 107-116. http://hrcak.srce.hr/82863

Geršić, S. (1974). Odgojno djelovanje putem izvannastavnih aktivnosti. Život i škola: časopis za teoriju i praksu odgoja i obrazovanja, 23(1-2), 87-91.

Guilford, J. P. (1959). Traits of Creativity. In H. Anderson (ed.), Creativitiy and its cultivation (pp. 143-161). New York: Harper - Brothers.

Karlavaris, B., \& Kraguljac, M. (1981). Razvijanje kreativnosti putem likovnog vaspitanja. Beograd: Prosveta. Kvaščev, R. (1974). Razvijanje stvaralačkih sposobnosti kod učenika: priručnik za nastavnike. Beograd: Zavod za udžbenike i nastavna sredstva.

Mlinarević, V., \& Brust Nemet, M. (2012). Izvannastavne aktivnosti u školskom kurikulumu. Osijek: Učiteljski fakultet Osijek.

Munitić, N. (1972). Rad s grupom recitatora. Život i škola: časopis za teoriju i praksu odgoja i obrazovanja, 21(1-2), 69-73.

Nemet, Z. (1969). Primjeri rada literarnih grupa. Život i škola: časopis za teoriju i praksu odgoja i obrazovanja, 18(5-6), 287-294.

Poljak, V. (1987). Stvaralaštvo i škola. Zagreb: Pedagoško-književni zbor. 
Previšić, V. (1987). Izvannastavne aktivnosti i stvaralaštvo. Zagreb: Školske novine.

Primorac, B., Šimeg, M., \& Šojat, A. (2010). Novinarstvo u školi. Zagreb: Školska knjiga.

Scher, A., \& Verrall, C. (2005). 100+ ideja za dramu. Zagreb: Hrvatski centar za dramski odgoj: Pili-poslovi d.o.o.

Stevanović, B. (1961). Stvaralačko mišljenje. Beograd: Rad.

Teplov, B. M. (1950). Stvaralačka delatnost. In Kornilov, Smirnov, Teplov (Eds.), Psihologija. Beograd: Naučna knjiga. Težak, S. (1979). Literarne, novinarske, recitatorske i srodne družine: priručnik za nastavnike. Zagreb: Školska knjiga.

Težak, S. (2002). Metodika nastave filma na općeobrazovnoj razini. Zagreb: Školska knjiga.

Vojvodić, L. (1972). U traganju za uspješnijim stvaralaštvom literarne družine. Život i škola: časopis za teoriju i praksu odgoja i obrazovanja, 21(1-2), 62-68.

Vukasović, A. (1976). Intelektualni odgoj. Zagreb: Izdavački zavod Jugoslavenske akademije.

\section{Web references}

Agricultural and Veterinary School (2014/2015). School Curriculum. http://ss-poljoprivredna-veterinarska-os.skole.hr/ Antun Mihanović Primary School (2014/2015). School Curriculum. http://www.os-amihanovica-os.skole.hr/ August Šenoa Primary School (2014/2015). School Curriculum. http://os-asenoa-os.skole.hr/ Civil Engineering and Geodesy School (2014/2015). School Curriculum. http://ss-graditeljsko-geodetska-os.skole.hr/ Crafts School (2014/2015). School Curriculum. http://ss-obrtnicka-os.skole.hr/

Davor Milas Trade and Commercial School (2014/2015). School Curriculum. http://ss-trg-kom-dmilas-os.skole.hr/ Dobriša Cesarić Primary School (2014/2015). School Curriculum. http://os-dcesaric-os.skole.hr/

Electrical Engineering and Traffic School (2014/2015). School Curriculum. http://www.ss-elektrotehnicka-prometna-os.skole.hr/

First Grammar School Osijek (2014/2015). School Curriculum. http://www.gimnazija-prva-os.skole.hr/

Fran Krsto Frankopan Primary School (2014/2015). School Curriculum. http://os-fkfrankopana-os.skole.hr/

Franjo Krežma Primary School (2014/2015). School Curriculum. http://os-krezme-os.skole.hr/

Grigor Vitez Primary School (2014/2015). School Curriculum. http://os-gvitez-os.skole.hr/

Hospitality and Tourism School (2014/2015). School Curriculum. http://ss-ugostiteljsko-turisticka-os.skole.hr/

Ivan Filipović Primary School (2014/2015). School Curriculum. http://os-ifilipovica-os.skole.hr/

Ivan Štark Center of Education (2014/2015). School Curriculum. http://centar-istark-os.skole.hr/

Jagoda Truhelka Primary School (2014/2015). School Curriculum. http://os-jtruhelke-os.skole.hr/

Jesuit Classical Grammar School in Osijek (2014/2015). School Curriculum. http://www.ikg.hr/

Ljudevit Gaj Primary School (2014/2015). School Curriculum. http://judevitgaj.hr/

Mechanical Engineering Technical School (2014/2015). School Curriculum. http://ss-strojarska-tehnicka-os.skole.hr/

Medical School (2014/2015). School Curriculum. http://ss-medicinska-os.skole.hr/

Mladost Primary School (2014/2015). School Curriculum. http://os-mladost-os.skole.hr/

Retfala Primary School (2014/2015). School Curriculum. http://os-retfala-os.skole.hr/

St. Ana Primary School (2014/2015). School Curriculum. http://os-svete-ane-os.skole.hr/

School of Art and Design (2014/2015). School Curriculum. http://www.umjetnicka-skola-osijek.hr/

Second Grammar School Osijek (2014/2015). School Curriculum. http://www.gimnazija-druga-os.skole.hr/

Tin Ujević Primary School (2014/2015). School Curriculum. http://os-tujevic-os.skole.hr/

Technical School and Ruđer Bošković Natural Sciences Grammar School (2014/2015). School Curriculum. http://ss-tehnicka-rboskovica-os.skole.hr/

Third Grammar School Osijek (2014/2015). School Curriculum. http://www.gimnazija-treca-os.skole.hr/

Vijenac Primary School (2014/2015). School Curriculum. http://os-vijenac-os.skole.hr/

Vladimir Becić Primary School (2014/2015). School Curriculum. http://os-vbecica-os.skole.hr/

Vocational School of Economics (2014/2015). School Curriculum. http://ss-ekonomska-upravna-os.skole.hr/

\section{$(\mathrm{Cc}) \mathrm{BY}$}

This work is licensed under a Creative Commons Attribution 3.0 License. 